TEACHER TALK IN ENGLISH CLASSROOM INTERACTION USING SINCLAIR AND COULTHARD MODEL

An Article

Presented as Partial Fulfillment of the Requirement for the Attainment of the Sarjana Pendidikan Degree in English Education

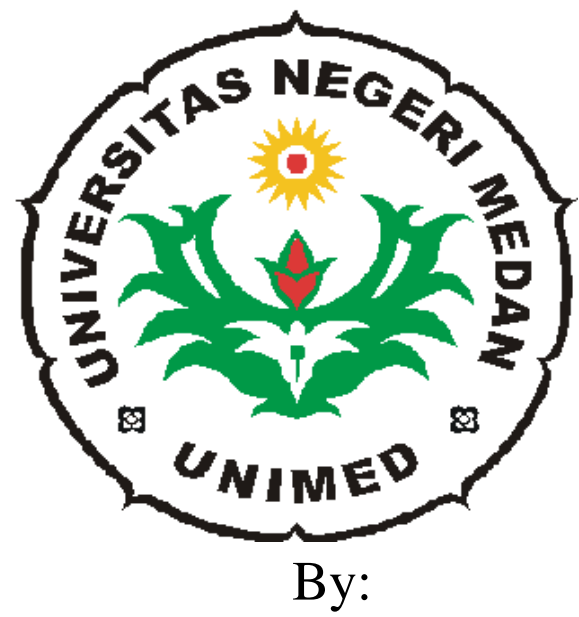

Friska Octavia

2133121029

ENGLISH EDUCATION DEPARTMENT

FACULTY OF LANGUAGES AND ARTS

STATE UNIVERSITY OF MEDAN

2017 


\title{
ARTIKEL \\ TEACHER TALK IN ENGLISH CLASSROOM INTERACTION USING SINCLAIR AND COULTHARD MODEL
}

\author{
Disusun dan Diajukan oleh: \\ Friska Octavia \\ NIM 2133121029
}

Telah diverifikasi dan dinyatakan memenuhi syarat

untuk diunggah pada jurnal online

Medan, $\quad$ November 2017

Menyetujui

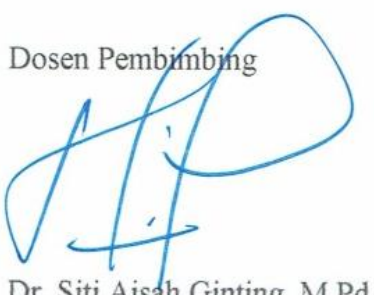

Dr. Siti Aisah Ginting, M.Pd NIP. 19505211984032002

\section{Dosen Pembimbing}

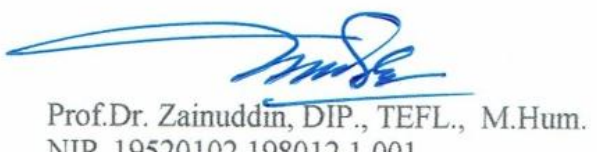

NIP. 195201021980121001

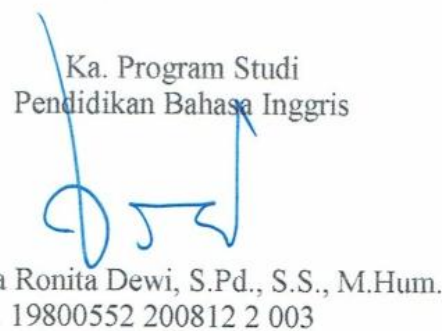


TEACHER TALK IN ENGLISH CLASSROOM INTERACTION USING

\author{
SINCLAIR AND COULTHARD MODEL \\ *Friska Octavia \\ **Dr. Siti Aisah Ginting, M.Pd. \\ **Prof. Dr. Zainuddin, DIP., TEFL., M.Hum.
}

\begin{abstract}
Friska Octavia: Registration Number: 2133121029. Teacher Talk in English Classroom Interaction Using Sincalir and Coulthard Model. A Thesis. English Educational Program, State University of Medan, 2017.
\end{abstract}

This study deals with teacher talk in English classroom interaction. The objectives of the study were: (a) to find out the types of moves found in the teacher talk used in English classroom interaction based on Sinclair and Coulthard model, and (b) to describe how the types of moves are realized in the teacher talk used in English classroom interaction based in Sinclair and Coulthard model. The design used in this study was qualitative research. The data of this study was the teacher's utterances. The data was collected by using audio recording and video recording. The data analysis of this study were based on Sinclair and Coulthard model as the following: (a) to find out the types of moves found in the teacher talk, and (b) to describe how the types of moves are realized in the teacher talk used in English classroom interaction. Based on the analysis of the data, the findings were shown as the following: (a) there were four types of moves found in the teacher talk, namely: opening, follow-up, framing and focusing, (b) the types of moves found in the teacher talk were mostly realized by $\mathbf{h}$. When the teacher got no response or got a wrong answer from the students, then the structure given was (s) h (post-h) (sel), the follow-up moves were mostly realized by (pre-h) $\mathbf{h}$, the framing moves were realized by $\mathbf{h} \mathbf{q}$ and the focusing moves were realized by $\mathbf{h}$. Based on the analysis of the data, some conclusions can be presented as the following: (a) the types of moves found in the teacher talk were opening, follow-up, framing and focusing, while the answering moves were not found in the teacher talk, which indicates that the classroom is not effective because there is no initiation from the students, (b) the opening moves were mostly realized by $\mathbf{h}$. When the teacher got no response or got a wrong answer from the students, then the structure given was (s) h (post-h) (sel), the follow-up moves were mostly realized by (pre-h) $\mathbf{h}$, the framing moves were realized by $\mathbf{h} \mathbf{q}$ and the focusing moves were realized by $\mathbf{h}$. Therefore, to create an effective English classroom, teacher should be able to recognize the moves she applies in her talk.

Keywords: Teacher talk, Classroom interaction, Move, Sinclair and Coulthard. 


\section{A. Background of Study}

Classroom interaction is the most important part in teaching and learning process since the purpose of the teaching and learning can be achieved only through it. For foreign language learners, classroom is the main place where they are frequently exposed to the target language. The kind of language used by the teacher for instruction in the classroom is known as teacher talk (Xiao-yan, 2006). Teacher talk depicts communicative approach to language teaching. (Nunnan, 1991) as cited in (Kiasi, 2014:96) asserts that teacher talk is of crucial importance, not only for the organization of the classroom but also for the processes of acquisition because it is probably the major source of comprehensible target language input the learner is likely to receive.

In this study, the researcher uses Sinclair and Coulthard model at the level of move to analyze the teacher talk during the interaction in the classroom. Move takes an important role to achieve the target of learning. Move is the starting point for the teacher to start the interaction to pass on the lesson to the students. By using the appropriate moves, teacher can stimulate the students to be actively involved in the classroom. In fact, in the moves exchanges during the interaction in the classroom, teacher's moves are not appropriate. When the teacher is opening the interaction for example, the teacher often does not pay attention to the moves.

T: Do you know what is meant by accent?

S: (silent)

$\mathrm{T}$ : It is the way we talk. 
In the dialogue, the teacher opens the interaction by directly asking a question without any introduction. Then the students keep silent. They do not answer the teacher's question. It is not because they do not know the answer, but the teacher does not pay attention to the appropriate move. Furthermore, when the students remain silent or do not answer the teacher's question, the teacher does not apply the appropriate move to stimulate the students' participation in the classroom. The teacher directly just answer the question, he/she does not try to start again using the same or a rephrased question, or the teacher can move to another students to get the answer.

\section{B. Conceptual Framework}

This study begins by intention to get information about types of move in teacher talk used by teacher in English classroom. To find out the types of moves in teacher talk, the Sinclair and Coulhard model proposed by Sinclair and Coulthard is applied in this study. There are 5 types of moves, namely: opening, answering, follow-up, framing and focusing. Those points are used as the focus to analyze the teacher talk.

This study also wants to investigate how the types of moves are realized in teacher talk in the English classroom interaction. To answer this question, the researcher uses the Sinclair and Coulthard model and will do observation toward the teacher talk during the teaching and learning process to obtain additional information. 


\section{Research Method}

This study was conducted by applying descriptive qualitative design. Qualitative research is a study that explores a problem and develops a detailed understanding of a central phenomenon (Creswell, 2012). This design was chosen because the fact that the study deals with language fenomenon as a social element.

The data were gathered by recording and observing the classroom interaction. The purpose of this study was to describe the teacher talk and focused on the moves applied by the teacher. The data of the research were the teacher's utterances which contained moves. The source of the data was the English teacher of SMK Multi Karya.

\section{Techniques of Analyzing Data}

This research used the data analysis from (Rymes, 2009) there were four basic steps including: recording real classroom interaction, observing the interaction and making preliminary observations, transcribing the verbal interaction, and the last, analyzing the transcription by using Sinclair and Coulthard model.

1. Recording real classroom interaction. To get the teacher talk, the researcher recorded the whole part of teaching and learning process in the classroom.

2. Observing interaction and making preliminary observations. The researcher observed the interaction by taking fieldnotes to see any event that was not cathed up by the recording. The observing involved on focal event, looking how it was patterned, and the sequences within it. 
3. Transcribing the verbal interaction. Here, the researcher wrote down what anyone says during the teaching and learning process.

4. Analyzing the transcription. Analyzing the transcription can be defined as coding scheme. At this step, the researcher analyzed the teacher talk in the transcription by using Sinclair and Coulthard model (1975) at the level of move. Then, found out the types of moves in teacher talk used in the English classroom and described how the types of moves were realized in teacher talk in the English classroom.

5. The conclusion was drawn from the data that had been summed up. After that, the researcher made the report of the research.

\section{Research Findings}

1. The types of moves found in the teacher talk used in English classroom interaction based on Sinclair and Coulthard model

The researcher found that there were four types of moves found in the teacher talk, namely: the opening moves, follow-up moves, framing moves and focusing moves. On the other hand, the answering move was not found.

2. The realization of types of moves in the teacher talk used in English classroom interaction based on Sinclair and Coulthard model

The opening moves found in the teacher talk were classified into four, namely: elicit, direct, inform and check. They were mostly realized by the compulsary element head $(\mathbf{h})$. When the teacher got no response or got a wrong answer from the students, the other elements appear in bound exchange. Then, the structure given was: (s) (h) (post- 
h) (sel) and would be so until the teacher got the expected answer. The follow-up moves were mostly structured by the elements (pre-h) (h).The teacher rarely, even almost never, gave comments to the students' response. All of he framing moves were structured by elements (h) (q). All of the focusing moves were structured by elements (h).

\section{E. Discussions}

1. Firstly, there were four types of moves found in the teacher talk used in English classroom interaction based on Sinclair and Coulthard model. There was no answering move appeared in the teacher talk beacuse there was no initiation move from the students. It was very unfortune, since this indicated that the students were reluctant to initiate the discourse although the teacher has already tried to stimulate them by using check or the other acts. Thus, the teacher dominated the classroom discourse. The previous relevant study about teacher talk conducted by Le and Liu (2012) revealed the same that teacher talked more than the students did in the classroom.

2. Secondly, the realization of types of moves found in the teacher talk takes an important role to stimulate the students' participation. The opening moves were mostly realized by the compulsary element head (h). This indicated that the teacher was not creative enough in opening the discourse. The researcher found that it rarely 
happened that the opening moves appeared in a full basic structure. This happened because probably the teacher did not know the moves. For instance, when the teacher opened the discourse by using elicitation, she firstly, asked the question without giving any clue. Therefore, the students did not give any response to the teacher's elicitation. Probably, the students did not know the answer or they were reluctant to respond. When this happened, the teacher would start again by using a rephrased question or moved on to the other students and thus, the other elements appeared making a full basic structure in bound exchange until she got the expected response. Then, the structure given was: (s) h (post-h) (sel).The follow-up moves were mostly structured by the elements (pre-h) h. The teacher rarely, even almost never, gave comments to the students' response. Probably because the teacher thought that the students just needed to know whether they performed adequately and thus the teacher just gave evaluation without comments.All of he framing moves were structured by elements $\mathbf{h}$ qas stated in the theory.The focusing moves were mostly structured by elements $\mathbf{h}$ The teacher rarely gave comments at the end of the focusing moves. Because what actually needed is the conslusion which summarizes what has been done. 


\section{F. Conclusions and Suggestions}

\section{Conclusions}

1. The types of moves found in the teacher talk used in English classroom interaction in SMK Multi Karya is dominated by the opening move. It is found that there were four types of moves, namely opening moves follow-up moves, framing moves and focusing moves, while the answering move is not found in the teacher talk because there is no initiation move from the students.

2. The opening moves found in the teacher talk are realized by: head (h). In case of the teacher got no response or got wrong answer, the opening moves are realized by: (s) h (post-h) (sel). The follow-up moves are realized by: (pre-h) $\mathbf{h}$. The framing moves are realized by: $\mathbf{h} \mathbf{q}$. The focusing moves are realized by: $\mathbf{h}$.

\section{Suggestion}

1. Teacher

It is necessary for the teachers to recognize the moves they use to interact with the students in the classroom to get the students' participations. By applying the appropriate moves, the teacher can stimulate the students' participations. Then, the class will run successfully. 


\section{Students}

The students should dare to speak up, because in the classroom they are allowed to do mistakes, and less outside the classroom.

\section{The next researcher}

It is finally suggested that the other researchers should conduct further studies about classroom discourse based on Sinclair and Coulthard model which will be a very useful reference to the teachers' and students' needs in teaching learning process. 


\section{REFERENCES}

Creswell. 2009. Educational Research: Planning, Conducting, Evaluating Quantitative and Qualitative Research (3rd edition). New Jersey: Pearson Education International.

Coulthard, M. (1992). Advances in spoken discourse analysis. London: Routledge

Kiasi, M. A \& Fatemeh, H. The Importance of 'Teacher Talk' in Teaching EFL Writing. Porta Linguarum. Iran: Payame Noor University.

Liu, J. \& Le, T. (2012). A case study on college English classroom discourse. International Journal of Innovative Interdisciplinary Research, 2, 1-11.

Nunan, D.1991. Language Teaching Methodology: A Textbook for Teachers. Cambridge: Cambridge University Press.

Rymes, B. (2008). Classroom discourse analysis: A tool for critical reflection. Cresskill, NJ: Hampton Press..

Sinclair, J. M. \& Coulhard, R. M. (1992). Towards an analysis of discourse. In M. Coulthard (Eds.), Advances in spoken discourse analysis (pp. 1-34). London: Routledge.

Xiaoyan, Ma. 2006. A Dissertation of Teacher Talk and EFL in University Classrooms. China: Chongqing Normal University \& Yangtze Normal University. 